\title{
Respon Tanaman Sorgum (Sorghum bicolor L.) Pada Tingkat Cekaman Salinitas Dengan Aplikasi Kalsium
}

\author{
Response of Sorgum (Sorghum bicolor L.) on Salinity Level with Calcium Application
}

\author{
Author(s): Pramukyana Lutfi ${ }^{(1)}$; Didik Puji Restanto ${ }^{(1) *}$; Ketut Anom Wijaya ${ }^{(1)}$ \\ (1) Universitas Jember \\ * Corresponding author: restanto.lemlit@unej.ac.id
}

\begin{abstract}
ABSTRAK
Sorgum merupakan salah satu tanaman yang sudah lama dibudidayakan di Indonesia namun dalam areal yang masih terbatas karena lahan pertanian yang subur dan produktif semakin menyempit. Kebanyakan lahan subur dan produktif tersebut pada umumnya lebih intensif ditanami padi dan terjadinya alih fungsi lahan subur untuk pembangunan industri, perumahan dan lain-lain. Salah satu upaya untuk mengembangkan komoditas sorgum adalah dengan memanfaatkan lahan marginal dekat pantai yang memiliki permasalahan yaitu memiliki tingkat salinitas yang tinggi. Permasalahan salinitas dapat dikendalikan dengan pemanfaatan unsur kalsium untuk menjaga agar tanaman sorgum dapat tumbuh secara optimum. Penelitian ini bertujuan memanfaatkan potensi lahan salin dan mengetahui dosis kalsium yang terbaik untuk menekan pengaruh dari cekaman salinitas untuk mengoptimalkan pertumbuhan tanaman sorgum. Percobaan ini dilakukan di rumah plastik buatan dengan menggunakan Rancangan Acak Lengkap (RAL), terdapat 2 faktor yang mana faktor pertama adalah tingkat salinitas yaitu $100 \mathrm{mM}, 150 \mathrm{mM}, 200 \mathrm{mM}$ dan $250 \mathrm{mM}$. Faktor kedua adalah perbedaan konsentrasi Kalsium Klorida $(\mathrm{CaCl} 2)$ yaitu $0 \mathrm{mM}, 10 \mathrm{mM}, 20 \mathrm{mM}$ dan $30 \mathrm{mM}$. Setiap kombinasi perlakuan diulang 3 kali. Varietas yang digunakan adalah Super 1. Variabel pengamatan meliputi tinggi tanaman, panjang akar, umur berbunga, umur panen, bobot biji per malai, kandungan klorofil, kadar air relatif daun dan kandungan prolin. Hasil penelitian menunjukkan bahwa perlakuan S0C1 (Cekaman salin $100 \mathrm{mM}+$ Kalsium $10 \mathrm{mM}$ ) memberikan hasil terbaik pada variabel tinggi tanaman dan panjang akar. Kombinasi perlakuan S0C2 (Cekaman salin $100 \mathrm{mM}+$ Kalsium $20 \mathrm{mM}$ ) memberikan hasil terbaik pada variabel bobot biji per malai, klorofil dan kadar air relatif.
\end{abstract}

\section{Kata Kunci:}

Sorgum,

Cekaman

salinitas,

aplikasi

kalsium.

\section{Keywords:}

Sorghum,

salinity stress,

calcium

application.

\section{ABSTRACT}

Sorghum has been cultivated for a long time, but in a limited area due to limited nutrient and productive agricultural land. Most of the productive land is intensively planted with rice and there is a change in the function of arable land for industrial development, housing, and others. One of the efforts to develop sorghum commodities is to utilize marginal land near the coast which has a problem, the problem was a high level of salinity. The problem of salinity can be controlled by utilizing Calcium to keep sorghum plants growing optimally. This study aims to exploit the potential of saline land and determine the optimum dose of calcium during salinity stress to optimize the growth of sorghum plants. This experiment was conducted in an artificial greenhouse using a randomized completely design (RCD) with 2 factors, the first factor was the salinity level consisted of 4 levels: $100 \mathrm{mM}, 150 \mathrm{mM}, 200 \mathrm{mM}$, and $250 \mathrm{mM}$. The second factor was the concentration of Calcium Chloride (CaCl2) consists of 4 levels: $0 \mathrm{mM}, 10 \mathrm{mM}, 20 \mathrm{mM}$, and $30 \mathrm{mM}$. The varieties used were Super 1. Each combination treatment was repeated 3 times. The observation variables included plant height, root length, flowering age, harvest age, seed weight per panicle, chlorophyll content, leaf relative water content, and proline content. The results showed that the combination of S0C1 treatment (saline stress $100 \mathrm{mM}+10 \mathrm{mM}$ calcium) had the best results on the variables of plant height and root length. The combination of S0C2 treatment (Saline stress $100 \mathrm{mM}+$ Calcium $20 \mathrm{mM}$ ) gave the best results for the variable seed weight per panicle, chlorophyll, and relative water content. 


\section{PENDAHULUAN}

Indonesia merupakan negara berkembang padat penduduk yang memilih beras menjadi bahan pangan pokok. Kebutuhan beras yang yang selalu meningkat setiap tahunnya menjadikan permasalahan bagi pemerintah untuk memnuhi kebutuhan beras sehingga melakukan impor dari negara lain. Dalam rangka mengurangi ketergantungan terhadap bahan pangan beras impor perlu dikembangkan bahan pangan lain untuk diversifikasi pangan. Salah satu bahan pangan alternatif yang menjadi perhatian saat ini adalah sorgum. Sorgum masih jarang dimanfaatkan untuk bahan pangan maupun industri di Indonesia. Budidaya sorgum sudah lama ada namun pada luasan lahan yang sangat (Alwi, 2014) lahan untuk pembangunan infrastruktur menjadi permasalahan yang belum dapat diatasi. Sebagai upaya pengembangan komoditas sorgum dapat dengan cara memanfaatkan lahan marginal dekat pantai yang mempunyai permasalahan tingkat salinitas yang tinggi. Salinitas adalah salah satu tekanan abiotik utama dalam pertanian di seluruh dunia yang membatasi produktivitas tanaman. Secara global, total lahan 831 juta hektar dipengaruhi oleh salinitas (Munns \& Tester, 2008).

Alwi (2014) mencatat luasan lahan pasang surut di Indonesia berkisar 20,12 juta ha. Dari luasan tersebut terdapat 0,44 juta hektar lahan yang tergolong salin. Total lahan salin di Indonesia diperkirakan sekitar 440.300 ha yang dibagi menjadi beberapa kriteria yaitu sebesar 304.000 ha dengan kriteria agak salin dan kriteria salin sebesar 140.300 ha (Rachman et al., 2007). Di Kabupaten Indramayu Jawa Barat terdapat $22,57 \%$ lahan salin dari luasan 102.321 ha dengan tiga status salinitas tanah yaitu rendah, sedang dan tinggi. Luas lahan salin di Kabupaten Lamongan dan Tuban diperkirakan mencapai 192.000 ha dengan tingkat salinitas sebesar 4,4-8,0 $\mathrm{dS} / \mathrm{m}$ (Balitkabi, 2015). Data menunjukkan terdapat kurang lebih 101,09 juta hektar lahan yang berpotensi untuk dikembangkan menjadi pertanian dan perkebunan yang terdiri dari lahan kering masam dan salinitas tinggi (Mulyani et al., 2016). Lahan yang dikategorikan sebagai lahan salin adalah lahan yang memiliki nilai EC (Electrical Condutivity) tinggi yaitu lebih dari 4,0 mmhos cm-1, memiliki kadar pH kurang dari 8,5 dan ESP (excangeable sodium persentage) dibawah $15 \%$ yang mana kondisi lahan tersebut dapat menghambat pertumbuhan tanaman (Waskim et al., 2012)

Sorgum merupakan tanaman $\mathrm{C} 4$ yang pada dasarnya lebih mudah beradaptasi pada lahan yang kering maupun kondisi lahan dengan salinitas yang tinggi ( $\mathrm{N}$ et al., 2021). Sorgum diklasifikasikan sebagai tanaman yang memiliki toleransi sedang terhadap garam dengan nilai salinitas sebesar $6 \mathrm{dS}$ m-1 dari ambang konduktivitas listrik (EC) (Vargas et al., 2018). Banyak penelitian menunjukkan bahwa penambahan kalsium bisa memengaruhi panjang zona pertumbuhan tanaman yang tercekam garam. Pada daun sorgum, panjang zona pertumbuhan dipersingkat oleh salinitas $\mathrm{NaCl} 100$ mM. Jika konsentrasi Ca dari larutan nutrisi meningkat dari 1 hingga 10 $\mathrm{mM}$, maka pemendekan zona pertumbuhan akibat salinitas dapat dicegah (Bernstein et al., 1993). Perlindungan $\mathrm{Ca} 2+$ pada tanaman yang tercekam salinitas adalah berperan dalam menjaga integritas membran, karena salah satu efek utama salinitas adalah gangguan integritas membran yang disebabkan oleh perpindahan $\mathrm{Ca} 2+$ dari permukaan sel oleh $\mathrm{Na}+$ (Heidari et al., 2011). Jafari et al (2009) juga melaporkan bahwa tambahan $\mathrm{Ca} 2+$ meningkatkan tinggi tanaman secara umum, aplikasi $20 \mathrm{mM} \mathrm{CaCl} 2$ dan $20 \mathrm{mM}$ $\mathrm{KCl}$ ke media akar dapat memperbaiki efek salinitas pada sorgum, terutama pada stres sedang dan tinggi. Tujuan dari penelitian ini yaitu untuk memanfaatkan potensi 
lahan salin dan mengetahui dosis kalsium yang terbaik untuk menekan pengaruh dari cekaman salinitas untuk mengoptimalkan pertumbuhan tanaman sorgum di Indonesia khususnya pada varietas Super 1.

\section{METODOLOGI}

Penelitian ini dilaksanakan pada bulan Mei 2019 sampai dengan bulan September 2019 bertempat di rumah plastik buatan di Desa Dukuh Dempok Kecamatan Wuluhan Kabupaten Jember, Laboratorium kultur jaringan Faperta Unej dan Laboratorium Biosains Politeknik Negeri Jember.

Penelitian menggunakan Rancangan Acak Lengkap (RAL) dengan 2 faktor dimana faktor pertama adalah tingkat salinitas yaitu $100 \mathrm{mM}, 150 \mathrm{mM}, 200 \mathrm{mM}$ dan $250 \mathrm{mM}$. Faktor kedua adalah perbedaan konsentrasi Kalsium Klorida $(\mathrm{CaCl} 2)$ yaitu $0 \mathrm{mM}, 10 \mathrm{mM}, 20 \mathrm{mM}$ dan $30 \mathrm{mM}$. Terdapat 16 kombinasi yang masing-masing kombinasi perlakuan diulang 3 kali. Varietas sorgum yang digunakan dalam penelitian ini adalah Super 1 .

Aplikasi perlakuan salinitas dilakukan dengan menyiramkan larutan $\mathrm{NaCl}$ ke dalam polibag sesuai perlakuan dengan volume $1000 \mathrm{ml} /$ polybag. Kemudian dilakukan perhitungan DHL (Daya Hantar Listrik) dengan cara menimbang $100 \mathrm{~g}$ campuran media tanam tanah dan petroganik ditambah dengan 500 $\mathrm{ml}$ aquades, lalu digojog sampai tercampur rata, diendapkan selama 24 jam, kemudian DHL diukur menggunakan EC meter. Jika hasil DHL sudah sesuai dengan kriteria salinitas yang telah ditentukan, dilakukan penambahan aplikasi kalsium klorida pada media tanam satu hari sebelum penanaman benih sorgum.

Variabel komponen pertumbuhan meliputi: tinggi tanaman, panjang akar, umur berbunga, umur panen dan bobot biji per malai. Variabel komponen fisiologi meliputi: kandungan klorofil dengan menggunakan klorofil meter, Kadar air relatif daun yang ditentukan dengan mengambil 10 potongan persegi dari daun sorgum dengan panjang $2 \mathrm{~cm}$. Potongan tersebut ditimbang untuk mengetahui bobot basah daun kemudian diletakkan ke dalam cawan petri berisi aquades pada suhu ruang selama 24 jam. Setelah 24 jam, potongan daun tersebut ditimbang untuk diperoleh bobot jenuhnya kemudian dikeringkan di oven pada suhu 80 oC selama 24 jam untuk mengetahui bobot keringnya. Kandungan prolin pada tanaman dianalisis menggunakan metode Bates et al (1973).

\section{HASIL DAN PEMBAHASAN}

Salah satu indikator menetapkan suatu lahan mengalami cekaman dan potensi salinitas adalah nilai electric conductivity (EC). Electric conductivity adalah kemampuan larutan dalam menghantarkan arus listrik. Tanah menjadi salin jika memiliki nilai $\mathrm{EC} \geq 4 \mathrm{dS} \mathrm{m}-1$ (Munns \& Tester, 2008). Sorgum diklasifikasikan sebagai tanaman yang memiliki toleransi sedang terhadap garam dengan nilai salinitas sebesar $6 \mathrm{dS}$ m-1 dari ambang konduktivitas listrik (EC) (FAO, 2005). Perlakuan pada salinitas $100 \mathrm{mM}$ menghasilkan nilai EC sebesar $6,08 \mathrm{dS} / \mathrm{m}$ sehingga sudah sesuai dengan batas toleransi cekaman salinitas tanaman sorgum. 
Author(s): Pramukyana Lutfi; Didik Puji Restanto; Ketut Anom Wijaya

Tabel 1. Nilai EC (Electric Conductivity) pada Beberapa Konsentrasi Garam Table 1. EC (Electrical Conductivity) Value at Several Salt Concentrations

\begin{tabular}{cccc}
\hline $\begin{array}{c}\text { Perlakuan } \\
\text { Salinitas }\end{array}$ & $\begin{array}{c}\text { EC Larutan Garam } \\
\mathrm{dS} / \mathrm{m}\end{array}$ & $\begin{array}{c}\text { EC Tanah Setelah } \\
\text { Perlakuan } \mathrm{dS} / \mathrm{m}\end{array}$ & $\begin{array}{c}\text { EC Tanah Setelah } \\
\text { Panen } \mathrm{dS} / \mathrm{m}\end{array}$ \\
Salinity & $\begin{array}{c}\text { EC's value Salt } \\
\text { Sreatment }\end{array}$ & $\begin{array}{c}\text { Solution } d S / \mathrm{m} \text { Value After } \\
\text { Treatment } \mathrm{dS} / \mathrm{m}\end{array}$ & $\begin{array}{c}\text { Soil EC Value After } \\
\text { Harvest } \mathrm{dS} / \mathrm{m}\end{array}$ \\
\hline $100 \mathrm{mM}$ & 12,27 & 6,08 & 0,58 \\
$150 \mathrm{mM}$ & 15,86 & 7,26 & 1,28 \\
$200 \mathrm{mM}$ & 19,76 & 7,97 & 3,16 \\
$250 \mathrm{mM}$ & 25,18 & 8,17 & 6,08 \\
\hline
\end{tabular}

\section{Komponen Pertumbuhan Tanaman Sorghum}

Tabel 2. Pengaruh cekaman salinitas dan aplikasi kalsium terhadap tinggi tanaman sorgum Table 2. Effect of salinity stress and calcium application on the height of sorghum plants

\begin{tabular}{ccrrr}
\hline \multirow{2}{*}{ Konsentrasi NaCl } & \multicolumn{4}{c}{ Tinggi Tanaman Plant Height } \\
\cline { 2 - 5 } NaCl concentration & \multicolumn{4}{c}{ Konsentrasi $\mathrm{CaCl}_{2}$ Concentrations of CaCl } \\
\cline { 2 - 5 } & $0 \mathrm{mM}$ & $10 \mathrm{mM}$ & $20 \mathrm{mM}$ & $30 \mathrm{mM}$ \\
\hline $100 \mathrm{mM}$ & $105.33 \mathrm{aA}$ & $111.17 \mathrm{aA}$ & $108.17 \mathrm{aA}$ & $100.17 \mathrm{aB}$ \\
$150 \mathrm{mM}$ & $92.67 \mathrm{bAB}$ & $94.67 \mathrm{bA}$ & $95.83 \mathrm{bA}$ & $102.83 \mathrm{aA}$ \\
$200 \mathrm{mM}$ & $90.67 \mathrm{bAB}$ & $101.67 \mathrm{aB}$ & $103.67 \mathrm{aA}$ & $100.00 \mathrm{aA}$ \\
$250 \mathrm{mM}$ & $87.33 \mathrm{cB}$ & $88.67 \mathrm{cA}$ & $102.00 \mathrm{aA}$ & $88.00 \mathrm{cA}$ \\
\hline
\end{tabular}

Keterangan: huruf kecil (Vertikal) dan huruf kapital (Horisontal). Angka yang diikuti huruf yang berbeda menunjukkan perbedaan yang nyata menurut uji DMRT taraf $5 \%$.

Note: lowercase (vertical) and capital letters (horizontal). Numbers followed by different letters show a significant difference according to the 5\% DMRT test.

Pada Tabel. 2 dapat dilihat bahwa perlakuan yang memiliki nilai tinggi tanaman yang paling baik adalah kombinasi cekaman salinitas $100 \mathrm{mM}+$ kalsium 10 mM. (Siregar, 2016) melaporkan bahwa tanaman sorgum yang ditanam pada kondisi salin antara 5-6 mmhos cm-1 mampu beradaptasi dengan baik. Perlakuan cekaman salinitas tertinggi yaitu $250 \mathrm{mM}$ tanpa ada penambahan kalsium menunjukkan hasil yang terendah yaitu $87.33 \mathrm{~cm}$.

Hal ini sejalan dengan hasil penelitian Latuharhary \& Saputro (2017) yang menunjukkan bahwa tinggi tanaman jagung yang paling rendah diperoleh pada cekaman salinitas dengan konsentrasi $\mathrm{NaCl}$ tertinggi yaitu $10.000 \mathrm{ppm}$. Semakin tinggi tingkat cekaman salinitas maka akan menurunkan pertumbuhan tinggi tanaman (Latuharhary \& Saputro, 2017). Penelitian lain juga menambahkan bahwa aplikasi $\mathrm{NaCl}$ pada fase vegetatif akan menghambat proses penyerapan air dan unsur hara sehingga tanaman menjadi kerdil (Mardhiana et al., 2018).

Pada Tabel 3 dan 4 menunjukkan bahwa terjadi interaksi antara perlakuan salinitas dengan penambahan kalsium pada variabel umur berbunga. Pada perlakuan cekaman salinitas $250 \mathrm{mM}+$ kalsium 0 $\mathrm{mM}$ menunjukkan umur berbunga paling cepat yaitu 39 HST. Semakin tinggi tingkat cekaman salinitas tanpa penambahan kalsium akan semakin mempercepat umur berbunga pada tanaman sorgum. Pada tabel 4.4 menunjukkan adanya interaksi antara perlakuan salinitas dengan penambahan kalsium pada variabel umur panen. Pada kombinasi cekaman salinitas $250 \mathrm{mM}+$ kalsium $0 \mathrm{mM}$ menunjukkan umur panen paling cepat yaitu 62 HST. Semakin tinggi 
tingkat cekaman salinitas tanpa penambahan kalsium akan semakin mempercepat umur panen pada tanaman sorgum. Berdasarkan penelitian (Siregar, 2016) pada sorgum varietas kawali yang tercekam salinitas menunjukkan umur berbunga yang lebih awal dari deskripsi

varietasnya 70 HST menjadi lebih awal yaitu 65 HST. Pernyataan dari Narwiyan et al., (2016) bahwa tanaman akan melakukan respon toleransi terhadap cekaman dengan mempercepat umur berbunga dan umur panen supaya siklus hidupnya lebih pendek.

Tabel 3. Pengaruh cekaman salinitas dan aplikasi kalsium terhadap umur berbunga tanaman sorghum

Table 3. Effect of salinity stress and calcium application on flowering age of sorghum plants

\begin{tabular}{|c|c|c|c|c|}
\hline \multirow{3}{*}{$\begin{array}{l}\text { Konsentrasi } \mathrm{NaCl} \\
\mathrm{NaCl} \text { concentration }\end{array}$} & \multicolumn{4}{|c|}{ Umur Berbunga Flowering Age } \\
\hline & \multicolumn{4}{|c|}{ Konsentrasi $\mathrm{CaCl}_{2}$ Concentrations of $\mathrm{CaCl}_{2}$} \\
\hline & $0 \mathrm{mM}$ & $10 \mathrm{mM}$ & $20 \mathrm{mM}$ & $30 \mathrm{mM}$ \\
\hline $100 \mathrm{mM}$ & $61.67 \mathrm{aA}$ & $60.33 \mathrm{aB}$ & $63.00 \mathrm{aA}$ & $61.00 \mathrm{aB}$ \\
\hline $150 \mathrm{mM}$ & $45.33 \mathrm{cA}$ & $56.33 \mathrm{bAB}$ & $53.33 \mathrm{bC}$ & $60.00 \mathrm{bA}$ \\
\hline $200 \mathrm{mM}$ & $41.00 \mathrm{cB}$ & $56.33 \mathrm{bAB}$ & $53.00 \mathrm{bC}$ & $58.67 \mathrm{bAB}$ \\
\hline $250 \mathrm{mM}$ & $39.00 \mathrm{cC}$ & $50.67 \mathrm{bC}$ & $55.00 \mathrm{bB}$ & $54.00 \mathrm{cB}$ \\
\hline
\end{tabular}

Keterangan: huruf kecil (Vertikal) dan huruf kapital (Horisontal). Angka yang diikuti huruf yang berbeda menunjukkan perbedaan yang nyata menurut uji DMRT taraf $5 \%$.

Note: lowercase (vertical) and capital letters (horizontal). Numbers followed by different letters show a significant difference according to the 5\% DMRT test.

Pada pengamatan panjang akar menunjukkan bahwa semakin tingginya tingkat cekaman salinitas maka panjang akar akan semakin pendek. Hal ini dapat dilihat pada Tabel 5 bahwa perlakuan S3C0 (cekaman salinitas $250 \mathrm{mM}$ dan tanpa aplikasi kalsium) menunjukkan hasil yang lebih rendah dibandingkan kombinasi perlakuan S0C1 (cekaman salinitas 100 $\mathrm{mM}+$ aplikasi kalsium $10 \mathrm{mM}$ ). Akar merupakan organ penyerap hara dan air dari dalam tanah,selain itu akar akan menjadi sensor apabila terjadi perubahan hara, air dan salinitas. Akar akan menyesuaikan morfologi untuk menyediakan sumberdaya sesuai dengan kapasitas maksimum (Galvan-Ampudia et al., 2013). Respon pertumbuhan perakaran bisa dilihat sebagai indikator untuk mengetahui toleransi tanaman terhadap cekaman.

Pada variabel pengamatan bobot biji per malai (Tabel 6) menunjukkan adanya interaksi antara perlakuan cekaman salinitas dengan aplikasi kalsium pada variabel pengamatan bobot biji per malai tanaman sorgum. Kombinasi perlakuan cekaman salinitas $100 \mathrm{mM}+$ aplikasi kalsium $20 \mathrm{mM}$ menunjukkan hasil bobot biji per malai paling baik yaitu 45,33 gr.

Bobot biji per malai terendah ditunjukkan oleh perlakuan cekaman salinitas $200 \mathrm{mM}+$ tanpa aplikasi kalsium. Semakin meningkatnya cekaman salinitas dan tanpa adanya aplikasi kalsium, akan menghasilkan bobot biji lebih rendah daripada perlakuan lainnya. Penurunan hasil tanaman ini karena terjadinya peningkatan salinitas akan merusak klorofil daun dan terjadi penghambatan pembentukan dan perkembangan biji sehingga menurunkan kompenen hasil (Taufiq \& Purwaningrahayu, 2013). Penelitian lain melaporkan bahwa aplikasi $\mathrm{NaCl}$ pada fase generatif mengakibatkan penurunan laju transpirasi berupa penutupan stomata daun. Hal ini akan menghambat proses fotosintesis akibat penurunan asimilasi $\mathrm{CO}^{2}$ dalam daun 
sehingga menghasilkan bobot segar yang rendah (Mardhiana et al., 2018).

Tanaman yang tercekam salinitas tinggi menunjukan nilai kandungan klorofil yang lebih rendah dibandingkan tanaman yang tercekam salinitas rendah (Tabel 7). Rendahnya kandungan klorofil tersebut karena adanya penurunan aktivitas fotosintesis pada tanaman. Selama fase awal salinitas terjadi, kapasitas penyerapan air oleh akar berkurang dan terjadi kehilangan air pada daun menjadi cepat akibat akumulasi dari garam yang tinggi di tanah dan tanaman. Hal ini mengakibatkan tanaman kekurangan suplai air yang dibutuhkan untuk proses fotosintesis (Rahnama et al., 2010).

Tabel 4. Pengaruh cekaman salinitas dan aplikasi kalsium terhadap umur panen tanaman sorghum

Table 4. Effect of salinity stress and calcium application on the harvest age of sorghum

\begin{tabular}{ccccc}
\hline \multirow{2}{*}{ Konsentrasi NaCl } & \multicolumn{4}{c}{ Umur Panen Harvest Age } \\
\cline { 2 - 5 }$N a C l$ Concentration & \multicolumn{4}{c}{ Konsentrasi CaCl $\mathrm{Cancentrations} \mathrm{of} \mathrm{CaCl}_{2}$} \\
\cline { 2 - 5 } & $0 \mathrm{mM}$ & $10 \mathrm{mM}$ & $20 \mathrm{mM}$ & $30 \mathrm{mM}$ \\
\hline $100 \mathrm{mM}$ & $86.00 \mathrm{aA}$ & $85.67 \mathrm{aA}$ & $87.67 \mathrm{aA}$ & $86.33 \mathrm{aA}$ \\
$150 \mathrm{mM}$ & $68.33 \mathrm{cA}$ & $75.33 \mathrm{bA}$ & $74.33 \mathrm{bB}$ & $78.67 \mathrm{aB}$ \\
$200 \mathrm{mM}$ & $67.33 \mathrm{cAB}$ & $74.00 \mathrm{bB}$ & $71.33 \mathrm{bC}$ & $78.00 \mathrm{aB}$ \\
$250 \mathrm{mM}$ & $62.00 \mathrm{cB}$ & $72.67 \mathrm{bC}$ & $74.33 \mathrm{bB}$ & $71.33 \mathrm{bC}$ \\
\hline
\end{tabular}

Keterangan: huruf kecil (Vertikal) dan huruf kapital (Horisontal). Angka yang diikuti huruf yang berbeda menunjukkan perbedaan yang nyata menurut uji DMRT taraf 5\%.

Note: lowercase (vertical) and capital letters (horizontal). Numbers followed by different letters show a significant difference according to the 5\% DMRT test.

Tabel 5. Pengaruh cekaman salinitas dan aplikasi kalsium terhadap panjang akar tanaman sorghum

Table 5. Effect of salinity stress and calcium application on root length of sorghum plants

\begin{tabular}{ccccc}
\hline Konsentrasi NaCl & \multicolumn{4}{c}{ Panjang Akar Root Lenght } \\
\cline { 2 - 5 } $\mathrm{NaCl}$ Concentration & \multicolumn{4}{c}{ Konsentrasi $\mathrm{CaCl}_{2}$ Concentrations of CaCl 2} \\
\hline $\mathrm{NaCl}$ & $0 \mathrm{mM}$ & $10 \mathrm{mM}$ & $20 \mathrm{mM}$ & $30 \mathrm{mM}$ \\
\hline $100 \mathrm{mM}$ & $22,07 \mathrm{aB}$ & $27,83 \mathrm{aA}$ & $19,73 \mathrm{bAB}$ & $19,97 \mathrm{aBC}$ \\
$150 \mathrm{mM}$ & $16,43 \mathrm{bC}$ & $20,47 \mathrm{bA}$ & $19,13 \mathrm{bB}$ & $15,97 \mathrm{cB}$ \\
$200 \mathrm{mM}$ & $14,73 \mathrm{cA}$ & $18,70 \mathrm{bB}$ & $18,57 \mathrm{bB}$ & $16,20 \mathrm{bC}$ \\
$250 \mathrm{mM}$ & $13,5 \mathrm{cBC}$ & $14,33 \mathrm{cA}$ & $12,50 \mathrm{cC}$ & $12,50 \mathrm{cC}$ \\
\hline
\end{tabular}

Keterangan: huruf kecil (Vertikal) dan huruf kapital (Horisontal). Angka yang diikuti huruf yang berbeda menunjukkan perbedaan yang nyata menurut uji DMRT taraf $5 \%$.

Note: lowercase (vertical) and capital letters (horizontal). Numbers followed by different letters show a significant difference according to the 5\% DMRT test. 
Tabel 6. Pengaruh cekaman salinitas dan aplikasi kalsium terhadap bobot biji per malai tanaman sorgum.

Table 6. Effect of salinity stress and application of calcium on seed weight per panicle of sorghum plants

\begin{tabular}{ccccc}
\hline \multirow{2}{*}{ Konsentrasi NaCl } & \multicolumn{4}{c}{ Bobot Biji per Malai Seed Weight per Panicle } \\
\cline { 2 - 5 } NaCl Concentration & \multicolumn{3}{c}{ Konsentrasi $\mathrm{CaCl}_{2}$ Concentrations of CaCl } \\
\cline { 2 - 5 } & $0 \mathrm{mM}$ & $10 \mathrm{mM}$ & $20 \mathrm{mM}$ & $30 \mathrm{mM}$ \\
\hline $100 \mathrm{mM}$ & $16,00 \mathrm{cA}$ & $36,33 \mathrm{aB}$ & $45,33 \mathrm{aA}$ & $26,33 \mathrm{bC}$ \\
$150 \mathrm{mM}$ & $12,00 \mathrm{cB}$ & $30,33 \mathrm{bB}$ & $43,67 \mathrm{abA}$ & $16,67 \mathrm{cA}$ \\
$200 \mathrm{mM}$ & $8,67 \mathrm{~dB}$ & $16,33 \mathrm{cAB}$ & $19,00 \mathrm{cA}$ & $11,33 \mathrm{cC}$ \\
$250 \mathrm{mM}$ & $12,33 \mathrm{cB}$ & $8,67 \mathrm{~dB}$ & $10,33 \mathrm{dA}$ & $11,67 \mathrm{cC}$ \\
\hline
\end{tabular}

Keterangan: huruf kecil (Vertikal) dan huruf kapital (Horisontal). Angka yang diikuti huruf yang berbeda menunjukkan perbedaan yang nyata menurut uji DMRT taraf $5 \%$.

Note: lowercase (vertical) and capital letters (horizontal). Numbers followed by different letters show a significant difference according to the 5\% DMRT test.

\section{Komponen Fisiologi}

Tabel 7. Pengaruh cekaman salinitas dan aplikasi kalsium terhadap klorofil tanaman sorghum

Table 7. Effect of salinity stress and calcium application on chlorophyll of sorghum plants

\begin{tabular}{ccccc}
\hline \multirow{2}{*}{ Konsentrasi NaCl } & \multicolumn{4}{c}{ Kandungan Klorofil Chlorophyll Content } \\
\cline { 2 - 5 }$N a C l$ Concentration & \multicolumn{4}{c}{ Konsentrasi $\mathrm{CaCl}_{2}$ Concentrations of CaCl 2} \\
\cline { 2 - 5 } & $0 \mathrm{mM}$ & $10 \mathrm{mM}$ & $20 \mathrm{mM}$ & $30 \mathrm{mM}$ \\
\hline $100 \mathrm{mM}$ & $44,83 \mathrm{bB}$ & $53,70 \mathrm{aA}$ & $54,83 \mathrm{aA}$ & $45,63 \mathrm{bB}$ \\
$150 \mathrm{mM}$ & $39,17 \mathrm{cA}$ & $46,70 \mathrm{aB}$ & $51,30 \mathrm{aB}$ & $42,30 \mathrm{bB}$ \\
$200 \mathrm{mM}$ & $38,90 \mathrm{cB}$ & $44,67 \mathrm{bB}$ & $49,73 \mathrm{abA}$ & $42,27 \mathrm{bB}$ \\
$250 \mathrm{mM}$ & $38,43 \mathrm{cB}$ & $47,87 \mathrm{bA}$ & $48,80 \mathrm{bA}$ & $38,77 \mathrm{cB}$ \\
\hline
\end{tabular}

Keterangan: huruf kecil (Vertikal) dan huruf kapital (Horisontal). Angka yang diikuti huruf yang berbeda menunjukkan perbedaan yang nyata menurut uji DMRT taraf $5 \%$.

Note: lowercase (vertical) and capital letters (horizontal). Numbers followed by different letters show a significant difference according to the 5\% DMRT test.

Kandungan klorofil pada tanaman yang tercekam salinitas cenderung lebih rendah disebabkan karena pada saat proses fotosintesis kekurangan suplai air dan hara pada tanaman. Penurunan serapan unsur hara seperti $\mathrm{N}$ dan $\mathrm{Mg}$ yang merupakan unsur penyusun klorofil menyebabkan sintesis klorofil rendah. (Nio Song \& Banyo, 2011).

Berdasarkan data pada tabel 8 menunjukkan bahwa terdapat interaksi antara perlakuan cekaman salinitas dengan aplikasi kalsium pada variabel pada variabel kadar air relatif daun. Interaksi antara perlakuan tersebut memberikan hasil sangat nyata dari interaksi antara kedua perlakuan tersebut memberikan hasil yang sangat nyata. Tabel 8 menunjukkan bahwa perlakuan S0C2 (Cekaman salinitas $100 \mathrm{mM}+$ kalsium 20 $\mathrm{mM}$ ) menghasilkan kadar air relatif sebesar 65,99 \%. Kadar air relatif (KAR) daun adalah suatu parameter yang menunjukkan respon ketahanan tanaman ketika terjai cekaman kekeringan dan salinitas. KAR dapat menunjukkan status air dan tekanan turgor dari sel-sel daun tanaman. 
Tabel 8. Pengaruh Cekaman Salinitas dan Aplikasi Kalsium Terhadap Kadar Air Relatif Tanaman Sorghum

Table 8. Effect of Salinity Stress and Calcium Application on The Relative Water Content of Sorghum Plants

\begin{tabular}{|c|c|c|c|c|}
\hline \multirow{3}{*}{$\begin{array}{c}\text { Konsentrasi } \mathrm{NaCl} \\
\mathrm{NaCl} \text { Concentration }\end{array}$} & \multicolumn{4}{|c|}{ Kadar Air Relatif Relative Water Content } \\
\hline & \multicolumn{4}{|c|}{ Konsentrasi $\mathrm{CaCl}_{2}$ Concentrations of $\mathrm{CaCl}_{2}$} \\
\hline & $0 \mathrm{mM}$ & $10 \mathrm{mM}$ & $20 \mathrm{mM}$ & $30 \mathrm{mM}$ \\
\hline $100 \mathrm{mM}$ & $52.94 \mathrm{aB}$ & $53.39 \mathrm{aB}$ & $65.99 \mathrm{aA}$ & $48.74 \mathrm{abC}$ \\
\hline $150 \mathrm{mM}$ & $46.59 \mathrm{bA}$ & $53.04 \mathrm{aB}$ & $57.01 \mathrm{bA}$ & $44.54 \mathrm{bA}$ \\
\hline $200 \mathrm{mM}$ & $44.21 \mathrm{bAB}$ & $51.02 \mathrm{abB}$ & $49.93 \mathrm{aC}$ & $42.85 \mathrm{bB}$ \\
\hline $250 \mathrm{mM}$ & $40.77 \mathrm{cB}$ & $43.95 \mathrm{bB}$ & $42.30 \mathrm{cA}$ & $43.96 \mathrm{bB}$ \\
\hline
\end{tabular}

Keterangan: huruf kecil (Vertikal) dan huruf kapital (Horisontal). Angka yang diikuti huruf yang berbeda menunjukkan perbedaan yang nyata menurut uji DMRT taraf $5 \%$.

Note: lowercase (vertical) and capital letters (horizontal). Numbers followed by different letters show a significant difference according to the 5\% DMRT test.

Tabel 9. Pengaruh cekaman salinitas dan aplikasi kalsium terhadap prolin tanaman sorghum Table 9. Effect of Salinity Stress and Application of Calcium on Sorghum Plant Proline

\begin{tabular}{ccccc}
\hline \multirow{2}{*}{ Konsentrasi NaCl } & \multicolumn{4}{c}{ Kandungan Prolin Proline Content } \\
\cline { 2 - 5 }$N a C l$ Concentration & \multicolumn{4}{c}{ Konsentrasi $\mathrm{CaCl}_{2}$ Concentrations of CaCl } \\
\cline { 2 - 5 } & $0 \mathrm{mM}$ & $10 \mathrm{mM}$ & $20 \mathrm{mM}$ & $30 \mathrm{mM}$ \\
\hline $100 \mathrm{mM}$ & $0,282 \mathrm{cA}$ & $0,259 \mathrm{cB}$ & $0,237 \mathrm{cB}$ & $0,345 \mathrm{bB}$ \\
$150 \mathrm{mM}$ & $0,433 \mathrm{aB}$ & $1,058 \mathrm{aAB}$ & $0,256 \mathrm{cAB}$ & $0,243 \mathrm{cB}$ \\
$200 \mathrm{mM}$ & $0,411 \mathrm{aB}$ & $0,298 \mathrm{bAB}$ & $0,285 \mathrm{cA}$ & $0,307 \mathrm{bB}$ \\
$250 \mathrm{mM}$ & $1,674 \mathrm{aA}$ & $0,471 \mathrm{aB}$ & $0,310 \mathrm{aB}$ & $0,420 \mathrm{aB}$ \\
\hline
\end{tabular}

Keterangan: huruf kecil (Vertikal) dan huruf kapital (Horisontal). Angka yang diikuti huruf yang berbeda menunjukkan perbedaan yang nyata menurut uji DMRT taraf $5 \%$.

Note: lowercase (vertical) and capital letters (horizontal). Numbers followed by different letters show a significant difference according to the 5\% DMRT test.

Cekaman salinitas menyebabkan turunnya tekanan turgor, sehingga stomata menutup dan serapan $\mathrm{CO} 2$ menurun menyebabkan fotosintat menurun. Pada kondisi cekaman salinitas terjadi tekanan osmotik pada lingkungan lebih tinggi daripada tekanan osmotik didalam sel tanaman, hal ini akan mengakibatkan tanaman sulit menyerap air, sehingga mengakibatkan defisit air. Untuk menghindari dehidrasi dan menjaga keseimbangan potensial air, sel dalam tanaman akan meningatkan konsentrasi zat terlarut intraseluler dan akan menurunkan potensial osmotik intraseluler sebagai pengatur beda potensial osmotik antara sel tanaman dan lingkungan (Demidchik \& Tester, 2002).

Berdasarkan tabel 9 dapat diketahui bahwa perlakuan cekaman salinitas pada pertumbuhan tanaman sorgum dapat berpengaruh terhadap kandungan prolin tanaman sorgum. Kandungan prolin tertinggi terdapat pada perlakuan $\mathrm{S} 3 \mathrm{C} 0$ (salinitas $250 \mathrm{mM}$ dan kalsium $0 \mathrm{mM}$ ) yaitu sebesar 1,67 $\mu \mathrm{mol} /$ gram berat segar daun. Respon tanaman terhadap cekaman garam adalah munculnya senyawa prolin, dimana prolin ini berperan dalam mengatur potensial osmotik dalam sitoplasma dan untuk melindungi membran plasmas dan protein (Wungrampha et al., 2018). Berdasarkan penelitian Kristiono (2018) 
konsentrasi prolin ini meningkat seiring dengan meningkatnya tingkat cekaman salinitas, lebih lajut (Hu et al., 2012) menjelaskan bahwa dibawah cekaman garam tanaman akan mudah kehilangan air, dengan adanya perbedaan tekanan osmotik yang kuat antara lingkungan dan tanaman menyebabkan tanaman sulit dalam menyerap air, sehingga terjadi defisit air.

\section{KESIMPULAN}

Berdasarkan hasil penelitian dapat ditarik kesimpulan bahwa peningkatan cekaman salinitas sangat berpengaruh terhadap respon pertumbuhan dan fisiologi tanaman sorgum. Pada tingkat cekaman salinitas $100 \mathrm{mM}$ menunjukkan hasil yang terbaik pada variabel tinggi tanaman, panjang akar, berat kering akar, klorofil dan kadar air relatif. Aplikasi kalsium memberikan pengaruh yang nyata pada semua variabel pengamatan sehingga penambahan kalsium untuk mengatasi permasalahan di lahan yang tercekam salinitas sangat efektif untuk diaplikasikan karena kalsium mampu mengurangi serapan $\mathrm{Na}^{+}$dan meningkatkan serapan $\mathrm{K}^{+}$ dan $\mathrm{Ca}^{2+}$ dengan baik, sehingga meningkatkan pertumbuhan tanaman. Perlakuan kalsium terbaik adalah sebesar $20 \mathrm{mM}$.

\section{DAFTAR PUSTAKA}

Alwi, M. (2014). Prospek lahan rawa EQ pasang surut untuk tanaman padi. Prosiding Seminar Nasional "Inovasi Teknologi Pertanian Spesifik Lokasi," 2007, 45-59.

Balitkabi. 2015. http://balitkabi.litbang. pertanian.go.id/berita/tantanganinovasi- untuk-memotensial-lahansalin-di-lamongan-dan-tuban/. Di akses pada tanggal 25 Januari 2021

Bates LS, Waldren RP, Teare ID. 1973. Rapid Determination of Free Proline for Water Stress Studies. Plant
Soil. 39: 205-207

Bernstein, N., Lauchli, A., \& Silk, W. K. 的 (1993). Kinematics and dynamics of sorghum (Sorghum bicolor L.) leaf development at various $\mathrm{Na} / \mathrm{Ca}$ salinities. I.Elongation growth. Plant Physiology, 103(4), 1107-1114.

Demidchik, V., \& Tester, M. (2002). 钢 Sodium fluxes through nonselective cation channels in the plasma membrane of protoplasts from Arabidopsis roots. Plant Physiology, 128(2), 379-387.

FAO. (2005). 20 hal untuk diketahui EQ tentang dampak air laut pada lahan di propinsi NAD. $1-8$.

Galvan-Ampudia, C. S., Julkowska, M. M., Darwish, E., Gandullo, J., Korver, R. A., Brunoud, G., Haring, M. A., Munnik, T., Vernoux, T., \& Testerink, C. (2013). Halotropism is a response of plant roots to avoid a saline environment. Current Biology, 23(20), 2044-2050.

Heidari, A., Toorchi, M., Bandehagh, A., EQ \& Shakiba, M. (2011). Effect of $\mathrm{NaCl}$ Stress on Growth , Water Relations , Organic and Inorganic Osmolytes Accumulation in Sunflower ( Helianthus annuus L .) Lines. Universal Journal of Environmental Research and Technology, 1(3), 351-362.

Hu, S., Tao, H., Qian, Q., Guo, L., \& others. (2012). Genetics and Molecular Breeding for SaltTolerance in Rice. Rice Genomics and Genetics, 3(1).

Jafari, M. H. S., Kafi, M., \& Astaraie, A. EQ (2009). Interactive effects of nacl induced salinity, calcium and potassium on physiomorphological 
traits of Sorghum (Sorghum bicolor L.). Pakistan Journal of Botany, 41(6), 3053-3063.

Kristiono, A., Purwaningrahayu, R. D., 镀 Taufiq, A., \& others. (2018). Respons Tanaman Kedelai, Kacang Tanah, dan Kacang Hijau Terhadap Cekaman Salinitas.

Latuharhary, R. A., \& Saputro, T. B. (2017). Respon Morfologi Tanaman Jagung (Zea mays) Varietas Bisma dan Srikandi Kuning pada Kondisi Cekaman Salinitas Tinggi. Jurnal Sains Dan Seni ITS, 6(2), 2-6.

Mardhiana, F., Soeparjono, S., \& Handoyo, T. (2018). Pengaruh Konsentrasi dan Waktu Aplikasi (NaCl) Terhadap Hasil dan Mutu Cabai Merah (Capsicum annum L.). Agriprima: Journal of Applied Agricultural Sciences, 2(1), 1-8.

Mulyani, A., Nursyamsi, D., \& Harnowo, ED. (n.d.). Potensi dan Tantangan Pemanfaatan Lahan Suboptimal untuk Tanaman Aneka Kacang dan Umbi.

Munns, R., \& Tester, M. (2008). EQ Mechanisms of salinity tolerance. In Annual Review of Plant Biology (Vol. 59, Issue May 2014).

N, M. Y., Dewi, E. S., Cot, J., Nie, T., Batu, M., \& Utara, A. (2021). Pemanfaatan Lahan Salin Tadah Hujan Untuk Budidaya Sorgum Utilization Of Rainfed Saline Land For Sorghum Cultivation Program Studi Agroekoteknologi , Fakultas Pertanian, Universitas Malikussaleh. $18,46-51$.

Narwiyan, N., Rosmayati, R., \& Bayu, E. S. (2016). Sebaran Normal Karakter Pertumbuhan dan Produksi Hasil
Persilangan Kedelai (Glycine max L. Merril) Varietas Anjasmoro Dengan Genotipa Kedelai Tahan Salin pada F2. Jurnal Agroekoteknologi Universitas Sumatera Utara, 4(4).

Nio Song, A., \& Banyo, Y. (2011).

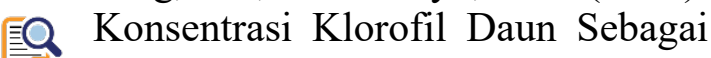
Indikator Kekurangan Air Pada Tanaman. Jurnal Ilmiah Sains, 15(1), 166.

Rachman, A., Subiksa, I. G. M., \& EQ Wahyunto. (2007). Perluasan Areal Tanaman Kedelai ke Lahan Suboptimal. Kedelai - Teknik Produksi Dan Pengembangan, 185204.

Rahnama, A., James, R. A., Scientific, T. EQ C., \& Munns, R. (2010). Stomatal conductance as a screen for osmotic stress tolerance in durum wheat growing in saline soil Stomatal conductance as a screen for osmotic stress tolerance in durum wheat growing in saline soil. January.

Siregar, Z. (2016). Respons Pertumbuhan Beberapa Varietas Sorgum (Sorghum Bicolor L.) Pada Tanah Salin Dengan Pemberian Giberelin. Agroekoteknologi, 4(3), 1996-2002.

Taufiq, A., \& Purwaningrahayu, R. D. 现 (2013). Tanggap Varietas Kacang Hijau Terhadap Cekaman Salinitas. Jurnal Penelitian Pertanian Tanaman Pangan, 32(3), 159-170.

Vargas, R., Pankova, E., Balyuk, A., 期 Krasilnikov, P., \& Khasankhanova, G. (2018). Handbook for saline soil management.

Waskim, R. M., Davis, J. G., Bauder, T., \& Andales, A. A. (2012). Diagnosing Saline and Sodic Soil Problems. Crop Series $\backslash$ Soil, Fact Sheet(0), 1-2. 
Wungrampha, S., Joshi, R., Singla-Pareek,

S. L., \& Pareek, A. (2018).

Photosynthesis and Salinity: Are

These Mutually Exclusive?

Photosynthetica, 56(1), 366-381. 